\title{
Chemical Stabilization of Chromate in Blast Furnace Slag Mixed Cementitious Materials
}

\author{
Amanda H. Meena ${ }^{1}$, Daniel I. Kaplan ${ }^{2}$, Brian A. Powell ${ }^{3}$, and Yuji Arai ${ }^{4 *}$ \\ ${ }^{1}$ School of Agricultural, Forest and Environmental Sciences, Clemson University Clemson, SC. \\ 29634 \\ ${ }^{2}$ Savannah River National Laboratory Aiken, SC 29808 \\ ${ }^{3}$ Department of Environmental Engineering and Earth Sciences Clemson University \\ Anderson, SC 29625 \\ ${ }^{4}$ Deaprtment of Natural Resources and Environmental Sciences, University of Illinois at Urbana- \\ Champaign, Urbana, IL 61801 \\ *Correspondence: Yuji Arai \\ E-mail:yarai@illinois.edu, office:(217)244-3602
}

\section{Keywords}

Reduction, Chromium, Technetium, Cement waste form, blast furnace slag, Immobilization

\begin{abstract}
Cement waste form (CWF) technology is among the leading approaches to disposing of metals and liquid low-level nuclear waste in the United States. One such material, saltstone, includes slag, fly ash and Portland cement to enhance the immobilization of contaminants (e.g.,


$\left.\mathrm{Cr},{ }^{99} \mathrm{Tc}\right)$ in alkaline liquid wastes. To evaluate the stability of such redox sensitive contaminants in saltstone, the effects of slag as a source of reductant on $\mathrm{Cr}$ immobilization was evaluated in aged $(<300 d)$ saltstone monoliths. Specifically, we investigated the effects of artificial cement porewaters on the $\mathrm{Cr}$ release and the spatially resolved $\mathrm{Cr}$ chemical state analysis using synchrotron based microfocused X-ray microprobe analysis. The microprobe analysis indicated the heterogeneous distribution of insoluble Cr(III)- species in saltstone. Although at most of $20 \%$ $\mathrm{Cr}_{\text {total }}$ was leached at the top few (2-3) millimeter depth, the release of $\mathrm{Cr}(\mathrm{VI})$ was small $(<5 \%)$ at 5-30 mm with slight changes, indirectly suggesting that $\mathrm{Cr}$ is likely present as insoluble $\mathrm{Cr}(\mathrm{III})$ species throughout the depths. The study suggests that this saltstone formulation can effectively retain/immobilize $\mathrm{Cr}$ under the oxic field condition after $\leq 300 \mathrm{~d}$ of aging time.

\section{Introduction}

In 2009, 136 million liters of liquid nuclear waste from nuclear plutonium production from the Cold War is still stored at the Savannah River Site (SRS) in Aiken, SC (Savannah River Remediation LLC. 2012). Approximately $10 \%$ of liquid nuclear waste is classified as the low- 
level nuclear waste (LLW) that contains technetium $\left({ }^{99} \mathrm{Tc}\right.$ ) as well as toxic heavy metals like $\mathrm{Cr}$ (Icenhower, et al., 2010; EPA, 2002).

Technetium and $\mathrm{Cr}$ exist as soluble oxyanions ( $\mathrm{Tc}(\mathrm{VII}) \mathrm{O}_{4}{ }^{-}$and $\left.\mathrm{Cr}(\mathrm{VI}) \mathrm{O}_{4}{ }^{2-}\right)$ in oxidized LLW. To immobilize these contaminants, one of solidification/stabilization methods, CWF immobilization method, is appealing to U.S. Department of Energy due to low cost, strict production regulations, permanence, and low temperature levels during manufacture (Atkins and Glasser. 1992). Cement technology has been widely used to stabilize hazardous heavy metals in solid phases (Bhatty et al., 1999; Cullinane et al., 1986; Li et al., 2001; Paria and Yuet. 2006). Chemical stabilization of metal contaminants is generally accomplished by reducing their solubility within the cement matrix. An effective CWF in use at SRS is called 'saltstone'. It has a standard composition of $6 \% \mathrm{wt}$, type 2 portland cement, $25 \% \mathrm{wt}$, fly ash, $25 \% \mathrm{wt}$, blast furnace slag (BFS), and 45 wt. \% salt solution (Savannah River Remediation, 2013). Blast furnace slag is included in the CWF formulation to increase strength, decrease porosity, and create a chemically reducing environment (Langton, 1987). Complete saltstone mixtures are dispositioned to the Saltstone Disposal Facility (SDF), a facility on the SRS that contains two rectangular near-surface vaults, as well as more recently constructed cylindrical units (Cook, 2005).

Both iron (Fe(II)) and sulfur $\left(\mathrm{S}(0), \mathrm{S}^{2-}\right)$ species within slag have been considered as important electron donors to reduce $\mathrm{Tc}(\mathrm{VII})$ and $\mathrm{Cr}(\mathrm{VI})$, resulting in the formation of $\mathrm{Tc}(\mathrm{IV})$ sulfur and or $\mathrm{Cr}$ (III) hydrous oxide species (Allen et al., 1997; Angus, M., F. Glasser. 1985 ). While $\mathrm{CrO}_{4}{ }^{2-}$ and $\mathrm{TcO}_{4}{ }^{-}$are highly soluble, these solid compounds have much lower solubilities and are therefore less mobile within the cement matrix. The successful immobilization of $\mathrm{Cr}$ and Tc in saltstone CWF remediation depends on the stabilization of $\mathrm{Cr}$ and $\mathrm{Tc}$ via reduction to 
prevent diffusion resulting from pore water contact, and the long-term resiliency and weathering of the saltstone (Savannah River Remediation, 2013). Consequently, the reducing environment within saltstone is imperative for effective containment, as oxygen diffusion into the cement matrix could result in rapid oxidation of $\mathrm{Tc}(\mathrm{IV}) / \mathrm{Cr}(\mathrm{III})$ species to soluble to $\mathrm{Cr}(\mathrm{VI}) \mathrm{O}_{4}{ }^{2-}$ and $\mathrm{Tc}(\mathrm{VII}) \mathrm{O}_{4}$. If this occurs, soluble oxyanions are likely to diffuse through pore fluid and microcracks, leading to a significantly greater leaching rate (Mattigod et al., 2009; Kaplan et al., 2011). Therefore, understanding the reducing capacity of saltstone is important for predicting the long-term behavior of CWFs.

Thus far, most studies have used indirect approaches (e.g., leaching tests) to investigate the reduction capacity of CWF using Tc and Cr (Langton, 1987; Langton et al., 2013; Almond et al., 201; Hang and Kaplan, 2007; Smith and Walton, 1992). Chromium is often used as a testing compound since its redox potential is more sensitive than Tc and it is non-radioactive. Under alkaline $\mathrm{pH}$ conditions of LLW, the standard reduction potential for Tc(IV/VII) is $-360 \mathrm{mV}$, which is lower than that of $\mathrm{Cr}(\mathrm{III} / \mathrm{VI})(-110 \mathrm{mV})$ (Bard et al., 1985; Magee and Cardwell. 1974). These values have an indication that $\mathrm{Tc}$ is more difficult to get reduced than $\mathrm{Cr}$; therefore subsequent $\mathrm{Cr}$ oxidation would be a useful indicator in predicting the Tc solubility in CWFs.

A bench mark leaching test conducted at the SRS showed that 0.035 cumulative fraction of Tc was leached over $\sim 3.5$ mo from saltstone (Langton, 1987). In other saltstone studies, they observed the development of oxidizing zone up to $7 \mathrm{~mm}$ depth after $\sim 1 \mathrm{mo}\left(2 \times 10^{-4}-0.17\right.$ fraction Cr leached) under oxic condition (Langton and Sefanko, 2012), $20 \mathrm{~mm}$ after $\sim 4 \mathrm{mo}$ ( up to 0.06 fraction $\mathrm{Cr}$ leached) (Langton et al., 2013) and $50 \mathrm{~mm}$ after $\sim 10 \mathrm{mo}$ (up to 0.04 fraction Cr leached) (Almond et al. 2013).

Furthermore, a two-dimensional reactive transport model was used to predict the Tc 
retention capacity in a saltstone block (Hang and Kaplan. 2007). The results showed that $~ 15.8 \%$ of the reduction capacity would be exhausted after 213,000 yrs. Hang and Kaplan (2007) later discussed that their estimate is in agreement with the results of empirical diffusion modeling based on measurements using X-ray absorption spectroscopy (Lukens, 2005).

There are some inconsistencies in describing the reducing capacity of saltstone between the results of leaching tests and modeling. The fraction of $\mathrm{Cr}(\mathrm{III})$ and the reduction capacity of saltstone samples have been measured concomitantly and there was no correlation (Almond et al., 2013). In order to evaluate these research outcomes to establish geochemical models to predict the long-term performance of saltstone, it would be useful to support the macroscopic leaching data with the direct chemical speciation data.

The objective of this study was to evaluate: 1) the solid state $\mathrm{Cr}$ speciation in the surface layer (up to $3 \mathrm{~cm}$ ) of field aged (135-290 days) saltstone monoliths, and 2) the extent of $\mathrm{Cr}$ release in artificial cement porewaters (deoxygenated $\mathrm{Ca}(\mathrm{OH})_{2}$ and oxygenated $\mathrm{CaCO}_{3}$ solutions to simulate the porewaters in young and old cement, respectively) as a function of depth. The surface layer was chosen because it is most sensitive to $\mathrm{O}_{2}$ diffusion. The general experimental approach was to couple the conventional leaching tests and synchrotron based X-ray microprobe analysis. The integrated results of Cr redox chemistry study in CWF should provide an important information about the reducing capacity of saltstone to immobilize $\mathrm{Cr}$ in LLW.

\section{Materials and Methods}

\section{Materials}

All reagents were prepared in degassed distilled deionized (DI) MilliQ water (18.2 M $\Omega$ ) using ACS grade chemicals unless otherwise mentioned. Chromate, as $\mathrm{Na}_{2} \mathrm{CrO}_{4}$, amended 
([Cr $]_{\text {Total: }} 500 \mathrm{mg} / \mathrm{kg}$ and $1000 \mathrm{mg} / \mathrm{kg}$ ) saltstone monolith (height: $10 \mathrm{~cm}$, O.D.: $25 \mathrm{~cm}$ ) were prepared using the method described by Almond and co-workers (2012). They are listed in Table-1. Sample preparation is described in detail and the radionuclide-free simulant mixture used for the saltstone samples is shown in Table-2. The simulant was combined with a premix of $45 \mathrm{wt}-\%$ BFS, $45 \mathrm{wt}-\%$ Class F fly ash, and $10 \mathrm{wt}-\%$ ordinary portland cement at a nominal 0.6 water to premix ratio. Elemental composition and mineralogy of these materials are summarized in Tables-3 and -4. Samples were cured in polypropylene cylinders in a humid chamber for one to three weeks. The samples were transferred to the Z-area at SRS for field aging in a closed chest with an open container of water inside.

\section{Segmentation and Leaching Tests}

Aged (250-280 days old) saltstone samples were handled inside of a $\mathrm{N}_{2}$ filled anaerobic glove chamber using a 5\% $\mathrm{H}_{2}$ and $95 \% \mathrm{~N}_{2}$ gas mixture. Each monolith was drilled in approximate millimeter increments using a Dremel 200 Drill equipped with a tungsten carbide drill bit. Since the oxidation is expected to progress from the surface, we were interested in the top $2-3 \mathrm{~cm}$ of monolith for this experiments. It was vertically mounted on a Dremel factory stand (Dremel 220-01 Rotary Tool Work Station) to ensure the accuracy of drilling depth. Depth was measured by inserting a ruler into the hole and measuring from the top of the sample. A $1.5 \mathrm{~cm}$ wide hole was drilled in the center of the samples to a depth of $3 \mathrm{~cm}$. Ground powder was collected at each increment and further ground in a Diamonite mortar and pestle. Then $\sim 0.5 \mathrm{~g}$ powder samples were transferred into two Nalgene Oak Ridge High-Speed Centrifuge tubes. The tubes contained $15 \mathrm{~mL}$ of two different leachate solutions (i.e., $0.001 \mathrm{M} \mathrm{CaCO}_{3}$ prepared in oxygenated MilliQ water, and $0.017 \mathrm{M} \mathrm{Ca}(\mathrm{OH})_{2}$ prepared in boiled/degassed DI water). These 
solutions were selected to simulate a simplified porewater in contact with a fresh cement $(0.017$ $\mathrm{M} \mathrm{Ca}(\mathrm{OH})_{2}$ at $\left.\mathrm{pH} 11.3 \pm 0.12\right)$ where the systems chemistry was controlled predominantly by portlandite, and an aged (thousands of years) cement $\left(0.001 \mathrm{M} \mathrm{CaCO}_{3}\right.$ at $\left.\mathrm{pH} 8.25 \pm 0.02\right)$, where the systems chemistry is controlled predominately by calcite (Criscenti et al., 1996; Krupka et al., 2012). Tubes were shaken on an end-over-end shaker at $26 \mathrm{rpm}$ for $24 \mathrm{hrs}$. The samples were then removed from the glove chamber and centrifuged at 10,500 rpm for eight min. The centrifugation method was sufficient to remove from suspension cement particles with a hydrodynamic radius greater than $100 \mathrm{~nm}$ to be removed from the supernatant. Approximately $10 \mathrm{~mL}$ of leachate was collected and filtered through a $0.2 \mu \mathrm{m}$ polyvinylidene fluoride (PVDF) filters. Filtrates were analyzed for total $\mathrm{Cr}(\mathrm{VI})$ using the following methods. The s-diphenyl carbazide UV-Vis spectrophotometric method (Bartlett and James, 1979; Fendorf, 2003) was used to analyze the filtrate for total hexavalent Cr. The data were normalized with respect to $[\mathrm{Cr}]_{\text {total }}$ added during the saltstone preparation.

\section{Synchrotron Based X-ray Microbe Analysis}

The microfocused $(\mu)$ synchrotron X-ray fluorescence (SXRF) measurements of a 135 days old saltstone monolith were performed at beam line 2-3 equipped with a double crystal Si(111) monochromator at Stanford Synchrotron Radiation laboratory, Menlo Park, CA. The monolith contains $\mathrm{Cr}_{\text {total }}$ of $1000 \mathrm{mg} / \mathrm{kg}$. A saltstone chip (W: $2 \mathrm{~cm} \times \mathrm{H} 3 \mathrm{~cm} \times$ D: $0.5 \mathrm{~cm}$ ) was separated from the top $2 \mathrm{~cm}$ of a monolith using a utility knife and a cement saw in an anaerobic

chamber. The selection of cross sectional area was to detect the development of oxidizing zone at the near surface. A chip was mounted in a custom made flow cell that was sealed with $8 \mathrm{~mm}$ Kapton tape. The outlet and inlet tubing of gas flow cells were clamped with alligator clips to 
trap $\mathrm{N}_{2}$ gas. Each cell was individually sealed in a Mylar bag with oxygen scrubbers. Chromium and valence state map measurements were conducted using a 7-element Ge solid-state detector. The energy calibration was performed at $5989 \mathrm{eV}$ using a $\mathrm{Cr}$ foil and at 10,534 eV. Beam size and dwell time were 3(H) x 5(V) $\mu \mathrm{m}$ and $200 \mathrm{~ms} /$ pixel, respectively. Selected absorption edge energies are $5993 \mathrm{eV}$ for $\mathrm{Cr}(\mathrm{VI}), 6003 \mathrm{eV}$ for $\mathrm{Cr}(\mathrm{III}), 6010 \mathrm{eV}$ for total $\mathrm{Cr}$. We selected $6003 \mathrm{eV}$ where the intensity ratio of $\mathrm{Cr}(\mathrm{III})$ and $\mathrm{Cr}(\mathrm{VI})$ reference spectra is maximized. We selected the energy of $5993 \mathrm{eV}$ that provides the maximum pre-edge peak height of $\mathrm{Cr}(\mathrm{VI})$, and the maximum white line peak for $\mathrm{Cr}(\mathrm{III})$ was chosen at $6010 \mathrm{eV}$.

Chromium K-edge $\mu$ X-ray absorption near edge structure spectroscopy (XANES) measurements were performed at regions selected from valence state maps. Three to four XANES spectra were collected in fluorescence mode using a Canberra 9-element Ge Array detector. Step sizes of $10 \mathrm{eV}, 0.35 \mathrm{eV}$, and $0.8 \mathrm{eV}$ were taken in the energy regions of 5880-5970 $\mathrm{eV}, 5970-6019 \mathrm{eV}$, and 6034-6080 eV, respectively. An integration time was $4 \mathrm{sec}$ at each step. To facilitate the analysis of $\mu$-XANES spectra, XANES spectra of reference compounds (ACS grade sodium chromate, $\mathrm{Cr}$ (III) oxide were also collected in transmission mode at ID-12 equipped with a double crystal $\mathrm{Si}(111)$ monochromator at Advanced Photon Sources, Argonne, IL. All salts were freshly ground and trapped in Kapton tape. Chemical composition maps and XANES spectra were processed using Smak and Sixpack software (Webb, 2005; Webb, 2006) The XAS data reduction and normalization was carried out as described by Arai et al.(2005). Valence state maps were generated according to the method described by Sutton et al. (2002).

\section{Results and Discussion}




\section{Chromate Leachability as a Function of Depth}

If one assumes the oxidation of $\mathrm{Cr}$ in saltstone is preceded by oxygen diffusion at shallow depth, two half-reactions (eq. 1 and 2) can be suggested in alkaline cement pore waters. Accordingly, the overall reaction can be written as follows (eq. 3):

$$
\begin{aligned}
& 4 \mathrm{Cr}(\mathrm{OH})_{3}(\mathrm{~s})+20 \mathrm{OH}^{-} \rightarrow 4 \mathrm{CrO}_{4}^{2-}+16 \mathrm{H}_{2} \mathrm{O}_{(\mathrm{l})}+12 \mathrm{e}^{-} \\
& \underline{3 \mathrm{O}}_{2(\mathrm{~g})}+6 \mathrm{H}_{2} \underline{\mathrm{O}+12 \mathrm{e}^{-} \rightarrow 12 \mathrm{OH}^{-}} \underline{(\mathrm{aq})}+ \\
& 4 \mathrm{Cr}(\mathrm{OH})_{3}(\mathrm{~s})+8 \mathrm{OH}^{-}+3 \mathrm{O}_{2(\mathrm{~g})} \rightarrow 4 \mathrm{CrO}_{4}{ }^{2-}+10 \mathrm{H}_{2} \mathrm{O}_{(\mathrm{l})}
\end{aligned}
$$

Using the average redox potential $(+36 \mathrm{mV})$ at the surface of saltstone reported in a similar saltstone study (Kaplan and Coates, 2007), the $\Delta \mathrm{G}$ of the reaction is estimated to be -156 $\mathrm{kcal} / \mathrm{mol}$, indicating that this reaction is thermodynamically favorable. Based on the thermodynamic calculation, one should expect to see $\mathrm{Cr}$ released if oxygen diffused into saltstone.

The Cr leaching data (Figs 1A and 1B) are shown as a function of leached $\mathrm{Cr}(\%)$ vs. increasing drill depth up to nearly three centimeters. The amount of $\mathrm{Cr}$ release was less than $20 \%$ of the total $\mathrm{Cr}$ at all depths and for both the 500 and $1000 \mathrm{mg} / \mathrm{kg}$ samples. The degree of chromate leaching was drastically decreased with increasing depths in both saltstone systems. There were spikes in the data that might suggest the heterogeneity of the sample matrices, where $\mathrm{Cr}$ may have concentrated in certain segments of the saltstone. When the $\mathrm{CaCO}_{3}$ solutions were used as a leachate solution, the difference was more pronounced than the $\mathrm{Ca}(\mathrm{OH})_{2}$ solution. The $\%$ Cr leached decreased from $20 \%$ to $10 \%$ with increasing depth from 0 to $5 \mathrm{~mm}$ in the $\mathrm{Cr} 500$ $\mathrm{mg} / \mathrm{kg}$ sample (Fig. 1A), while $\% \mathrm{Cr}$ leached decreased from $\sim 4$ to $2 \%$ with increasing the depth 
from 0 to $10 \mathrm{~mm}$ in the $\mathrm{Cr} 1000 \mathrm{mg} / \mathrm{kg}$ sample (Fig. 1B). It is important to note that the contribution of background $\mathrm{Cr}$ to total $\mathrm{Cr}$ leached in control monoliths (i.e., no $\mathrm{Cr}$ spokes) was less than $3.6 \%$ of total $\mathrm{Cr}$ leached. For this reason, observed trend is attributed to the speciation changes in the spiked Cr. While the amount of total chromate leached slightly decreased with increasing depth (Figs 1A and 1B), the decrease in total chromate leached (from $20 \%$ to $7 \%$ in the $500 \mathrm{mg} / \mathrm{kg} \mathrm{Cr}$ sample and $4.5 \%$ to $1 \%$ in the $1000 \mathrm{mg} / \mathrm{kg} \mathrm{Cr}$ sample) was not enough to warrant the fully oxidizing condition in either sample.

\section{Effects of leaching solutions on $\mathrm{Cr}$ (VI) Release}

The range of chromate leaching in both 500 and $1000 \mathrm{mg} / \mathrm{kg}$ samples was generally greater in the oxygenated $\mathrm{CaCO}_{3}$ solutions as compared to the deoxygenated $\mathrm{Ca}(\mathrm{OH})_{2}$ solutions. For example, in the $500 \mathrm{mg} / \mathrm{kg} \mathrm{Cr}$ sample, the chromate concentrations ranged from 2.70$20.18 \%$ in the $\mathrm{CaCO}_{3}$ leachate and only $0.48-6.13 \% \mathrm{Cr}(\mathrm{VI})$ leached in the $\mathrm{Ca}(\mathrm{OH})_{2}$ leachate (Fig. 1A). Similarly, in the $1000 \mathrm{mg} / \mathrm{kg} \mathrm{Cr}$ sample, the Cr(VI) concentrations ranged from 0.77$4.40 \% \mathrm{Cr}(\mathrm{VI})$ leached in the $\mathrm{CaCO}_{3}$ leachate and only $0.02-1.58 \% \mathrm{Cr}(\mathrm{VI})$ leached in the $\mathrm{Ca}(\mathrm{OH})_{2}$ leachate (Fig. 1B). For the $\mathrm{Cr}(\mathrm{VI})$ leaching from the $\mathrm{Cr} 500 \mathrm{mg} / \mathrm{kg}$ sample, the average leached at all depths was $3.51 \%$ less for the $\mathrm{Ca}(\mathrm{OH})_{2}$ compared to the $\mathrm{CaCO}_{3}$ leachate. In the $\mathrm{Cr} 1000 \mathrm{mg} / \mathrm{kg}$ sample, the difference in chromate leaching between leachate solutions was less pronounced at $1.58 \%$.

The retention of $\mathrm{Cr}$ in saltstone is expected through reductive precipitation reactions. It is well documented that the reduction of $\mathrm{Cr}(\mathrm{VI})$ would lead to the formation of stable $\mathrm{Cr}$ (III) oxyhydroxide phases (e.g., $\left.\mathrm{Cr}(\mathrm{OH})_{3},\left(\mathrm{Cr}_{\mathrm{x}}, \mathrm{Fe}_{1-\mathrm{x}}\right)(\mathrm{OH})_{3(\mathrm{~s})}\right)$ at $\mathrm{pH}$ range $\sim 6-12$ (Davis and Olsen, 1995; Papassiopi, 2012). Our synchrotron based microprobe data also show the presence of $\mathrm{Cr}(\mathrm{III})$ phases in the saltstone (see the section below). If one assumes the presence of $\mathrm{Cr}(\mathrm{OH})_{3}$ in 
saltstone, the following leaching mechanisms can be proposed to support the experimental evidence above. They are 1) oxidative dissolution of $\mathrm{Cr}(\mathrm{III})$ precipitates in the oxygenated $\mathrm{CaCO}_{3}$ solutions, 2) $\mathrm{Ca}$ enhanced co-sorption of $\mathrm{Cr}(\mathrm{VI})$ in the degassed $\mathrm{Ca}(\mathrm{OH})_{2}$ solutions and 3) carbonate enhanced desorption of $\mathrm{Cr}(\mathrm{VI})$.

The oxidative dissolution of $\mathrm{Cr}(\mathrm{OH})_{3}$ is likely facilitating the release of $\mathrm{Cr}(\mathrm{VI})$ in the oxygenated $0.001 \mathrm{M} \mathrm{CaCO}_{3}$ system. Chromium(III) might have been already oxidized during aging, and or slowly oxidized during the desorption experiments. Under oxidizing conditions, it has been reported the accelerated dissolution of $\mathrm{Cr}(\mathrm{OH})_{3}$ occurs via oxidation of $\mathrm{Cr}(\mathrm{III})$ to Cr(VI) (Lee and Hering, 2005).

pH-dependent dissolution of $\mathrm{Cr}(\mathrm{OH})_{3}$ was also considered. Rai and co-workers (1987) previously discussed the amphoteric dissolution property of $\mathrm{Cr}(\mathrm{OH})_{3}$ in $0.1 \mathrm{M}$ perchlorate medium. The solubility decreased from $\mathrm{pH} 4$ to $\sim 6$ and increased again around $\mathrm{pH} 10$ due to the formation of soluble $\mathrm{Cr}(\mathrm{OH}) \mathrm{x}^{-(\mathrm{x}-3)}{ }_{(\mathrm{aq})}$ hydrolysis product. Due to the lower leaching of $\mathrm{Cr}$ in $\mathrm{Ca}(\mathrm{OH})_{2}(\mathrm{pH} 11.3 \pm 0.12)$ compared to $\mathrm{CaCO}_{3}(\mathrm{pH} 8.25 \pm 0.12)$, it is unlikely that $\mathrm{pH}$ dependent solubility of $\mathrm{Cr}(\mathrm{OH})_{3}$ is controlling $[\mathrm{Cr}]$.

Additionally, dissolved Ca may facilitate the retention of $\mathrm{Cr}(\mathrm{VI})$ in alkaline soils (Avudainayagam et al., 2001). The activity of $\mathrm{Ca}^{2+}$ in the $\mathrm{Ca}(\mathrm{OH})_{2}$ solution herein was estimated at $8.34 \cdot 10^{-3}$, which is greater than that in the $\mathrm{CaCO}_{3}$ leaching solution $\left(7.55 \cdot 10^{-4}\right)$. This difference in $\mathrm{Ca}^{2+}$ activity indirectly suggests the enhanced $\mathrm{Cr}(\mathrm{VI})$ sorption might have been occurring in saltstone mineral components (e.g., gypsum, hydrotalcite tri- and di-calcium silicate, tricalcium aluminate and calcium silicate hydrate) (Cozzi and Duncan. 2011), resulting in less $\mathrm{Cr}(\mathrm{VI})$ release in the degassed $\mathrm{Ca}(\mathrm{OH})_{2}$ solution. 
Under the experimental condition, high bicarbonate concentration could have enhanced the desorption of $\mathrm{Cr}(\mathrm{VI})$ anions via ligand exchange mechanisms. It is known that carbonate is strongly complex on the mineral surfaces (Villalobos et al., 2001).

\section{Synchrotron Based X-ray Microprobe Analysis}

Results of synchrotron based microprobe analysis are shown in Figs 2A-2D. In the sodium chromate reference spectrum (Fig. 2C), there is a large pre-edge peak (a vertical dotted line at $5993 \mathrm{eV}$ ). The pre-edge resonances of Cr K-edge XANES spectra are characteristic for the local symmetry of tetrahedral coordination of $\mathrm{Cr}(\mathrm{VI}) \mathrm{O}_{4}$ molecules. Since the tetrahedral structure symmetry causing considerable overdue of empty d-orbitals with the p-states that the photoelectron must fill (Newville, 2004). Since the tetrahedral structure lacks an inversion center, it

exhibits a single intense pre-edge peak which is indicative of a dipole transition of 1s electron to an unoccupied anti bonding $\mathrm{t}_{2} *$ tetrahedral orbital. On the contrary, the XANES spectrum of $\mathrm{Cr}(\mathrm{III})_{2} \mathrm{O}_{3}$ shows lack of feature at the pre-edge region, allowing for a distinction between the two valences using the pre-edge feature of XANES spectra.

\section{Chromium Valence State in Saltstone}

A saltstone chip from a Cr $1000 \mathrm{mg} / \mathrm{kg}$ sample (Fig. 2A) aged for $~ 134$ days was analyzed for the distribution of Cr. To account for the sample heterogeneity, a large Cr XRF map ( $0.8 \mathrm{~mm} \times 18.8 \mathrm{~mm}$ ) was taken (Fig $2 \mathrm{~A})$, showing a distinct distribution pattern of $\mathrm{Cr}$ in cement matrices at top $\sim 2 \mathrm{~cm}$ depth. Although the surface of cement is rough, $\mathrm{Cr}$ is distributed throughout the depth. The higher intensity in a color contour bar corresponds to higher $\mathrm{Cr}$ content, while the top section $(1.01 \times 0.99 \mathrm{~mm})$ was used for a $\mathrm{Cr}(\mathrm{VI})$ valence state map (Fig. 2B). The increasing intensity in the valence state map corresponds to $\mathrm{Cr}(\mathrm{VI})$ valence state in the heterogeneous 
media. In the valence state map, dark blue corresponds to void spaces in the saltstone matrix, such as the one shown in Fig. 2D. Correlation plots of Cr constructed from microprobe analysis (Figure 2B) are shown in Fig. 3. The scatter plot of Cr(VI) vs. Cr(III) (Fig. 3) shows that most of the $\mathrm{Cr}$ is present as $\mathrm{Cr}(\mathrm{III})$ (probably as insoluble $\mathrm{Cr}(\mathrm{OH})_{3}$ ) while some high fluorescence counts for $\mathrm{Cr}(\mathrm{VI})$ are shown where the fluorescence counts of $\mathrm{Cr}(\mathrm{III})$ are low. As it can be seen in a comparison of $\mathrm{Cr}(\mathrm{III})$ and $\mathrm{Cr}(\mathrm{VI})$ reference spectra (Fig 2C ), the fluorescence intensity at 6003 $\mathrm{eV}$ is overlapped in a mixed oxidation sample (i.e., a large $\mathrm{Cr}$ (III) contribution with a small background from $\mathrm{Cr}(\mathrm{VI}))$. Therefore, it is important to assure the interpretation of scatter plots. For this reason, selected fluorescence counts (a hollow circle on Fig. 2B.) were back transformed into a X-ray fluorescence (XRF) map. There are few isolated $\mathrm{Cr}(\mathrm{VI})$ high-intensity hotspots visible in this map, which were chosen for XANES analysis (Fig. 2C). Furthermore, the corresponding XANES spectra show that the Cr speciation in the hot-spots is predominately Cr(III). We conducted linear combination of reference compound fit at 5920-6020eV using the $\mathrm{Cr}(\mathrm{III})$ and $\mathrm{Cr}(\mathrm{VI})$ reference compounds shown in Fig 2 . The $\mathrm{Cr}(\mathrm{III})$ fraction was $96.4 \%( \pm 0.2)$ at spot $1,97.0 \%( \pm 0.2)$ at spot $2,99.1 \%( \pm 0.2)$ at spot $3,97.0 \%( \pm 0.3)$ at spot 4 , and $96.5 \%( \pm 0.3)$ at spot 5, suggesting the $\mathrm{Cr}$ valence state is predominantly $\mathrm{Cr}(\mathrm{III})$.

This is evident because of the lack of a $\mathrm{Cr}(\mathrm{VI})$ pre-edge feature (i.e., predominantly $\mathrm{Cr}(\mathrm{III})$ ), which can be seen in the $\mathrm{Cr}(\mathrm{VI})$ standard, in the XANES from the saltstone segment. This is in agreement with only $20 \%$ of chromate released in the Cr leaching tests.

The reduction of $\mathrm{Cr}(\mathrm{VI})$ has been studied in cement mixtures using XAS technique. In a similar study, $1000 \mathrm{mg} / \mathrm{kg} \mathrm{CrO}_{4}{ }^{2-}$ spiked cement mixtures (47\% BFS, 47\% FA, 6\% PC) aged 28 days were analyzed by XANES and found to contain between 2-3\% of Cr(VI) content. Using the same cement mixture, Lee and co-workers (1995) spiked samples with $2500 \mathrm{mg} / \mathrm{kg} \mathrm{Na}_{2} \mathrm{CrO}_{4}$ 
and cured for 9 days (Lee et al., 1995). Chromium was estimated to be $75 \% \mathrm{Cr}$ (III) and $25 \%$ $\mathrm{Cr}(\mathrm{VI})$ by XANES and EXAFS analysis, which is similar to the amount of $\mathrm{Cr}(\mathrm{VI})$ released in our leaching tests $(\leq 20 \%)$. The speciation of $\mathrm{Cr}(\mathrm{III})$ was suggested as $\mathrm{Cr}(\mathrm{OH})_{3}$ in the cement and $\mathrm{CrOOH}$ in a BFS only mix (Lee et al., 1995). Their results agree with our findings that little $\mathrm{Cr}(\mathrm{VI})$ is visible in our valence state maps and XANES data due to successful reduction of $\mathrm{Cr}(\mathrm{III})$ in saltstone and lower loading of $\mathrm{Cr}$ in our samples.

\section{Conclusions}

The results of $\mathrm{Cr}$ leaching analysis in degassed $\mathrm{Ca}(\mathrm{OH})_{2}$ solution showed no apparent oxidization was occurring in saltstone samples with a total aging time of $<300$ days. Instead, there was some residual $\mathrm{Cr}(\mathrm{VI})$ release at the top few millimeters of monoliths (maximum of $20 \%$ and $4 \%$ for Cr 500 and $1000 \mathrm{mg} / \mathrm{kg}$, respectively). Depth dependent Cr(VI) release was not clearly observed at the 5-30mm depth. X-ray microprobe analysis showed the majority of Cr was stabilized as $\mathrm{Cr}(\mathrm{III})$. The presence of $\mathrm{Cr}$ (III) oxidation in these samples suggests that the reducing compounds present in saltstone have not prevented or reversed Cr oxidation. However, when the samples were exposed to oxygenated $\mathrm{CaCO}_{3}$ solution (i.e., simulated aged cement pore waters), the $\mathrm{Cr}(\mathrm{VI})$ leaching slightly increased, indirectly suggesting that subtle increases in $\mathrm{O}_{2}$ content via diffusion could potentially oxidize $\mathrm{Cr}(\mathrm{III})$ to $\mathrm{Cr}(\mathrm{VI})$.

\section{Acknowledgement}

This research was supported by the South Carolina Universities Research and Education Foundation, Contract No. DE-AC09-08SR22470. Portions of this work were performed at BL2-3 
at SSRL and ID-12 at APS. These facilities are supported by the U.S. Department of Energy, Office of Science, Office of Basic Energy Sciences under Contract No. DE-AC02-76SF00515 and No. DE-AC02-06CH11357, respectively.

\section{References}

Allen, P.G., Siemering, G.S., Shuh, D.K., Bucher, J.J., Edelsteign, N.M., Langton, C.A., Clark, S.B., Reich, T., Denecke, M.A., 1997. Technetium speciation in cement waste forms determined by x-ray absorption fine structure spectroscopy, Radiochim. Acta. 76,77-86.

Almond, P., Kaplan, D., Langton, C., Stefanko, D., Spencer, W., Hatfield, A., Arai, Y., 2012. Method evaluation and field sample measurements for the rate of movement of the oxidation front in saltstone. Savannah River National Laboratory SRNL-STI-2012-00468. 
Almond, P., Stefanko, D., Langton. C., 2013. S.R. Site, Cementitious barriers partnership effect of oxidation on chromium leaching and redox capacity of slag-containing waste forms.

Cementitious Barriers Partnership CBP-TR-2013-02.

Angus, M., Glasser, F., 1985. The chemical environment in cement matrices. MRS Proceedings. Cambridge Univ. Press. 50 .

Arai, Y., Sparks D.L., Davis, J.A., 2005. Arsenate adsorption mechanisms at the allophane-water interface: Environ. Sci. Technol. 39,2537-2544.

Atkins, M., Glasser, F., 1992. Application of Portland cement-based materials to radioactive waste immobilization, Waste Manage. 12,105-131.

Avudainayagam, S., Naidu, R., Kookana, R.S., Alston, A.M., McClure, S., Smith, L.H., 2001. Effects of electrolyte composition on chromium desorption in soils contaminated by tannery waste, Aust. J. Soil. Res. 39,1077-1089.

Bard, A.J., Parsons, R., Jordan, J., 1985. Standard Potentials in Aqueous Solution, Marcel Dekker, Inc, New York, New York.

Bartlett, R., James, B, 1979. Behavior of chromium in soils: III. Oxidation. J. Environ. Qual. 8, $31-35$.

Bhatty, J.I., Miller, F., West, P.B., Ost, B., 1999. Stabilization of heavy metals in portland cement, silica fume/portland cement and masonry cement matrices, Portland Cement Association. PCA RP348. Skokie, IL. 
Cook, J.R., Wilhite, E.L., Hiergesell, R.A., Flach. G.P., 2005. Special analysis: Revision of saltstone vault 4 disposal limits. Westinghouse Savannah River Company WSRC-TR-200500074. Aiken SC.

Criscenti, L., Serne, R., Krupka, K., Wood, M., 1996. Predictive calculations to assess the longterm effect of cementitious materials on the $\mathrm{pH}$ and solubility of uranium(VI) in a shallow land disposal environment. Pacific Northwest National Laboratory PNNL-11182. Richland, WA.

Cozzi, A., Duncan, A., 2011. Characterization of core sample collected from the Saltstone Disposal Facility. In: Sundaram, S.K., Ohji, T., Fox, K., Hoffman, E., (Eds.), Advances in Materials Science for Environmental and Nuclear Technology II, John Wiley \& Sons, New Jersey. p.135.

Cullinane, M.J., Jones, L.W., Malone, P.G., 1986. Handbook for stabilization/solidification of hazardous waste, Hazardous Waste Engineering Research Laboratory, Office of Research and Development, US Environmental Protection Agency, 1986. Cincinnati, OH.

Davis, A., Olsen, R.L., 1995. The geochemistry of chromium migration and remediation in the subsurface, Ground Water. 33,759-768.

EPA facts about technetium-99. 2002. http://www.epa.gov/superfund/health/contaminants/radiation/pdfs/technetium.pdf

Fendorf, S., 2003. Kinetics and structural constraints of chromate reduction by green rusts, Environ. Sci. Technol. 37,2750-2757. 
Hang, T., Kaplan, D.I., 2007. Modeling of the sub-surface reducing environment of the Z-Area Saltstone disposal facility at the Savannah River Site. Westinghouse Savannah River Company WSRC-STI-2005-00367. Aiken, SC.

Icenhower, J.P., Qafoku, N.P., Zachara, J.M., Martin, W.J., 2010. The biogeochemistry of technetium: a review of the behavior of an artificial element in the natural environment, Am. J. Sci. 310,721-752.

Kaplan, D., Lilley, M., Almond, P., Powell, B., 2011. Long-term technetium interactions with reducing cementitious materials, Savannah River National Laboratory SRNL-STI-2010-00668.

Krupka, K.M., Cantrell, K.J., Schaef, H.T., Arey, B.W., Heald, S.M., Deutsch, W.J., Lindberg, M.J., 2012. Characterization of solids in residual wastes from single-shell tanks at the Hanford Site, Washington, USA.

Kaplan, D.I., Coates, J.T., 2007. Partitioning of dissolved radionuclides to concrete under scenarios appropriate for tank closure performance assessments. Westinghouse Savannah River Company WSRC-STI-2007-00640.

Langton, C., 1987. Slag-based saltstone formulations. MRS Proceedings. Cambridge Univ. Press. 112 .

Langton, C., Stefanko, D., 2012. Oxidation study: Chromium and Rhenium leaching front results. Savannah River National Laboratory SRNL-L3100-2012-00033. Aiken, SC. 
Langton, C., Stefanko, D., Burns, H., 2013. Saltstone oxidation study: leaching method.

Savannah River National Laboratory SRNL-STI-2012-00728.

Lee, G., Hering, J.G., 2005. Oxidative dissolution of chromium (III) hydroxide at pH 9, 3, and 2 with product inhibition at pH 2, Environ. Sci. Technol. 39,4921-4928.

Lee, J., Bajt, S., Clark, S., Lamble, G., Langton, C., Oji, L., 1995. Chromium speciation in hazardous, cement-based waste forms, J. Phys. Cond. Matter. 208 \& 209,577-578.

Li, X., Poon, C., Sun, H., Lo, I., Kirk, D., 2001. Heavy metal speciation and leaching behaviors in cement based solidified/stabilized waste materials, J. Hazard. Mater. 82,215-230.

Lukens, W.W., Bucher, J.J., Shuh, D.K., Edelstein, N.M., 2005. Evolution of technetium speciation in reducing grout, Environ. Sci. Technol. 39, 8064-8070.

Magee, R.J., Cardwell, T.J., 1974. Rhenium and technetium, in: Encyclopedia of Electrochemistry of the Elements, Marcel Dekker, New York. p. 126.

Mattigod, S.V., Bovaird, C.C., Wellman, D.M. Skinner, D.C.J., Cordova, E.A., Wood, M.I., 2009. Effect of concrete waste form properties on radionuclide migration. Pacific Northwest National Laboratory PNNL-18745. Richland, WA.

Newville, M. 2004. Fundamentals of X-ray absorption fine structure. Consotium for Advanced Radiation Sources, University of Chicago. http://xafs.org

Papassiopi, N., 2012. Stabilization of chromium in the form of mixed Fe(III)-Cr(III) hydroxides, Fresenius Environmental Bulletin. 21,2399-2405. 
Paria, S., Yuet, P.K., 2006. Solidification-stabilization of organic and inorganic contaminants using Portland Cement: a Literature Review, Env. Rev.14:217-255.

Rai, D., Sass, B.M., Moore, D.A., 1987. Chromium (III) hydrolysis constants and solubility of chromium (III) hydroxide, Inorg. Chem. 26,345-349.

Savanna River Remediation Saltstone disposal units. 2013. www.srremediation.com/ saltstone.pdf

Smith, R.W.,Walton, J.C., 1992. The role of oxygen diffusion in the release of technetium from reducing cementitious waste forms. MRS Proceedings. Cambridge Univ. Press. 294.

Sutton S.R., Bertsch P.M., Newville M., Rivers M.L., Lanzirotti A., Eng P.J.. 2002. Microfluorescence and microtomography analyses of heterogeneous earth and environmental materials In: Applications of synchrotron radiation at low-temperature geochemistry and environmental sciences, Review in Mineralogy and Geochemistry Vol. 49 (ed. Fenter, P.A., Rivers, M.L., Sturchio, N.C., Sutton S.R.) Chantilly, VA: Mineralogical Society of America. pp. $429-483$.

Um, W., Valenta, M.M., Chung, C.W., Yang, J., Engelhard, M.H., Serne, R.J., Parker, K.E., Wang, G., Cantrell, K.J., Westsik, J.H., 2011. Radionuclide retention mechanisms in secondary waste-form testing: phase II. Pacific Northwest National Laboratory PNNL-20753.

Villalobos, M., Trotz, M A., Leckie, J. O.2001. Surface complexation modeling of carbonate effects on the adsorption of $\mathrm{Cr}(\mathrm{VI}), \mathrm{Pb}(\mathrm{II})$, and $\mathrm{U}(\mathrm{VI})$ on goethite. Environ. Sci. Technol.35, 3849-3856. 
Webb, S.M., 2005. SIXpack: a graphical user interface for XAS analysis using IFEFFIT. Phys.

Scr. 1011.

Webb S.M., 2006. SMAK: Sam's Microprobe Analysis kit, V0.46. Stanford Synchrotron

Radiation Laboratory, Menlo Park, CA. 
Table-1. Description of $\mathrm{Cr}(\mathrm{VI})$ amended saltstone samples and the chemical composition of leaching solutions. The $\mathrm{Ca}(\mathrm{OH})_{2}$ and $\mathrm{CaCO}_{3}$ based leaching solutions were prepared in boiled and oxygenated MilliQ water, respectively.

\begin{tabular}{ccc}
\hline $\begin{array}{c}\text { Chemical amendments in } \\
\text { saltstone (mg/kg) }\end{array}$ & Aging time in field (days) & $\begin{array}{c}\text { Chemical } \\
\text { composition of } \\
\text { leaching solutions }\end{array}$ \\
\hline $\mathrm{Na}_{2} \mathrm{CrO}_{4} 500$ & 253 & $0.001 \mathrm{M} \mathrm{CaCO}$ \\
$\mathrm{Na}_{2} \mathrm{CrO}_{4} 500$ & 272 & $0.017 \mathrm{M} \mathrm{Ca}(\mathrm{OH})_{2}$ \\
$\mathrm{Na}_{2} \mathrm{CrO}_{4} \quad 1000$ & 289 & $0.017 \mathrm{M} \mathrm{Ca}(\mathrm{OH})_{2}$ \\
$\mathrm{Na}_{2} \mathrm{CrO}_{4} \quad 1000$ & 279 & $0.001 \mathrm{M} \mathrm{CaCO}$ \\
\hline
\end{tabular}

e-2. Chemical composition of artificial Tank 50

simulant used in saltstone preparation (Almond et al., 2012)

\begin{tabular}{lc}
\hline \multicolumn{1}{c}{ Compound } & Concentrations (M/L) \\
\hline $\mathrm{Al}\left(\mathrm{NO}_{3}\right)_{3} \cdot 9 \mathrm{H}_{2} \mathrm{O}$ & 0.11 \\
$\mathrm{NaOH}$ & 1.55 \\
$\mathrm{Na}_{2} \mathrm{SO}_{4}$ & 0.05 \\
$\mathrm{Na}_{2} \mathrm{CO}_{3}$ & 0.14 \\
$\mathrm{NaNO}_{3}$ & 2.11 \\
$\mathrm{NaNO}_{2}$ & 0.33 \\
\hline
\end{tabular}

\begin{tabular}{|c|c|c|c|c|c|c|c|c|c|c|}
\hline$(\mathrm{wt} \%)$ & $\mathrm{Al}_{2} \mathrm{O}_{3}$ & $\mathrm{CaO}$ & $\mathrm{BaO}$ & $\mathrm{CeO}_{2}$ & $\mathrm{CoO}$ & $\mathrm{Cr}_{2} \mathrm{O}_{3}$ & $\mathrm{Fe}_{2} \mathrm{O}_{3}$ & $\mathrm{~K}_{2} \mathrm{O}$ & MgO & $\mathrm{MnO}_{2}$ \\
\hline Slag & 8.41 & 37.9 & 0.041 & 0.01 & 0 & 0.022 & 0.352 & 0.295 & 12.9 & 0.572 \\
\hline Fly Ash & 28.5 & 0.678 & 0.114 & 0.028 & 0.015 & 0.051 & 6.11 & 2.58 & 0.911 & 0.035 \\
\hline Cement & 5.44 & 64.7 & 0.022 & 0.009 & 0 & 0.019 & 3.65 & 0.479 & 1.21 & 0.027 \\
\hline$(\mathrm{wt} \%)$ & $\mathrm{Na}_{2} \mathrm{O}$ & $\mathrm{NiO}$ & $\mathbf{P}_{2} \mathrm{O}_{5}$ & $\mathrm{SO}_{4}$ & $\mathrm{SiO}_{2}$ & SrO & $\mathrm{TiO}_{2}$ & $\mathrm{~V}_{2} \mathrm{O}_{5}$ & $\mathrm{ZnO}$ & $\mathrm{ZrO}_{2}$ \\
\hline
\end{tabular}




\begin{tabular}{lrrrrrrrrrr}
\hline \multirow{2}{*}{ Slag } & 0.247 & 0.005 & 0 & 0.906 & 38.1 & 0.033 & 0.381 & 0 & 0 & 0.026 \\
Fly Ash & & & & & & & & & & \\
& 0.25 & 0.02 & 0.094 & 0.102 & 54.4 & 0.063 & 1.58 & 0.052 & 0 & 0.041 \\
Cement & & & & & & & & & & \\
& 0.12 & 0.011 & 0.245 & 3.21 & 20.5 & 0.086 & 0.331 & 0.032 & 0.048 & 0 \\
\hline
\end{tabular}

Table-3: Elemental composition of slag, fly ash, and cement used in this study.

\begin{tabular}{ll}
\hline Component & \multicolumn{1}{c}{ Mineralogy } \\
\hline Fly Ash & Quartz, mullite, hematite, magnetite, maghemite, calcite, and portlandite \\
Blast furnace slag & Akermanite, quartz, calcite, monoticelite \\
Portland cement & Alite, belite, tricalcium aluminate, gypsum and calcium aluminoferrite \\
\hline $\begin{array}{l}\text { Table-4: Bulk Mineralogy determined using X-ray diffraction measurements of saltstone } \\
\text { components. }\end{array}$
\end{tabular}

\section{Figure captions}

Fig. 1. Results of metal leaching data in $\mathrm{CaCO}_{3}$ and $\mathrm{Ca}(\mathrm{OH})_{2}$ leaching solutions are shown in black squares and open triangles, respectively. A) $\mathrm{Cr}(\mathrm{VI})$ leaching data from the $\mathrm{Cr} 500 \mathrm{mg} / \mathrm{kg}$ sample. B) $\mathrm{Cr}(\mathrm{VI})$ leaching data from the $\mathrm{Cr} 1000 \mathrm{mg} / \mathrm{kg}$ sample. To clearly show the data points in the $\mathrm{Cr}$ data, error bars for $\mathrm{Cr}(\mathrm{VI})$ (\% error range: $2.1-4.3$ ) are not shown. 
Fig. 2. Results of synchrotron based microprobe analysis of $134 \mathrm{~d}$ aged $\mathrm{Cr} 1000 \mathrm{mg} / \mathrm{kg}$ saltstone sample. A) Total Cr XRF map (0.8mm x 18.8mm) at the depth of 0-18.8 mm. B) Cr(VI) valence state map $(0.8 \mathrm{~mm} \times 1.01 \mathrm{~mm})$ at the depth of $0-1.01 \mathrm{~mm}$. C) Normalized bulk Cr K-edge XANES spectra of reference compounds and $\mathrm{Cr}(\mathrm{VI})$ hotspots in B. D) A section of total Cr XRF map from Fig. 2A showing a large void (in dark blue) in saltstone matrix.

Fig. 3. Correlation plots constructed from synchrotron based microprobe results of $\mathrm{Cr} 1000$ $\mathrm{mg} / \mathrm{kg}$ saltstone (XRF map shown in Fig. 2B). Intensity of the $\mathrm{Cr}(\mathrm{VI})$ pre-edge peak plotted against the ratio of $\mathrm{Cr}(\mathrm{III})(6003 / 5993 \mathrm{eV})$. 

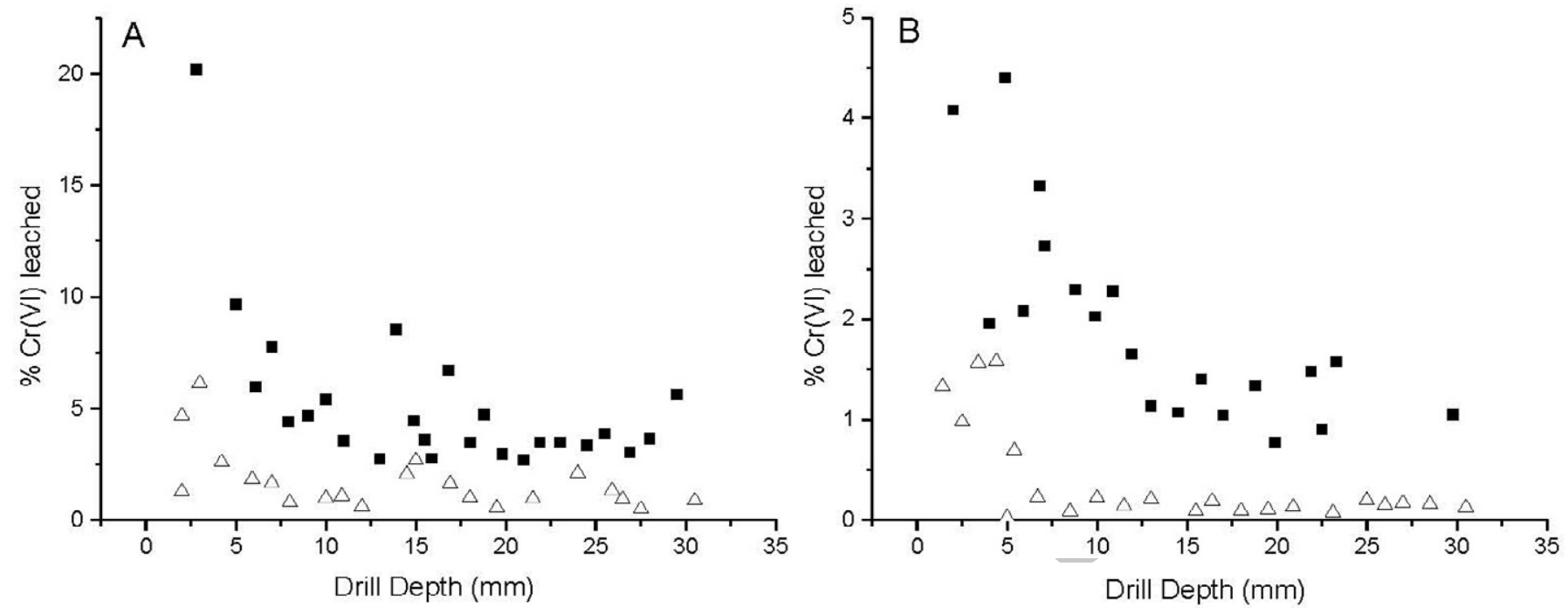

Fig. 1. Results of metal leaching data in $\mathrm{CaCO}_{3}$ and $\mathrm{Ca}(\mathrm{OH})_{2}$ leaching solutions are shown in black squares and open triangles, respectively. A) $\mathrm{Cr}(\mathrm{VI})$ leaching data from the $\mathrm{Cr} 500 \mathrm{mg} / \mathrm{kg}$ sample. B) $\mathrm{Cr}(\mathrm{VI})$ leaching data from the $\mathrm{Cr} 1000 \mathrm{mg} / \mathrm{kg}$ sample. To clearly show the data points in the $\mathrm{Cr}$ data, error bars for $\mathrm{Cr}(\mathrm{VI})$ (\% error range: 2.1- 4.3) are not shown. 


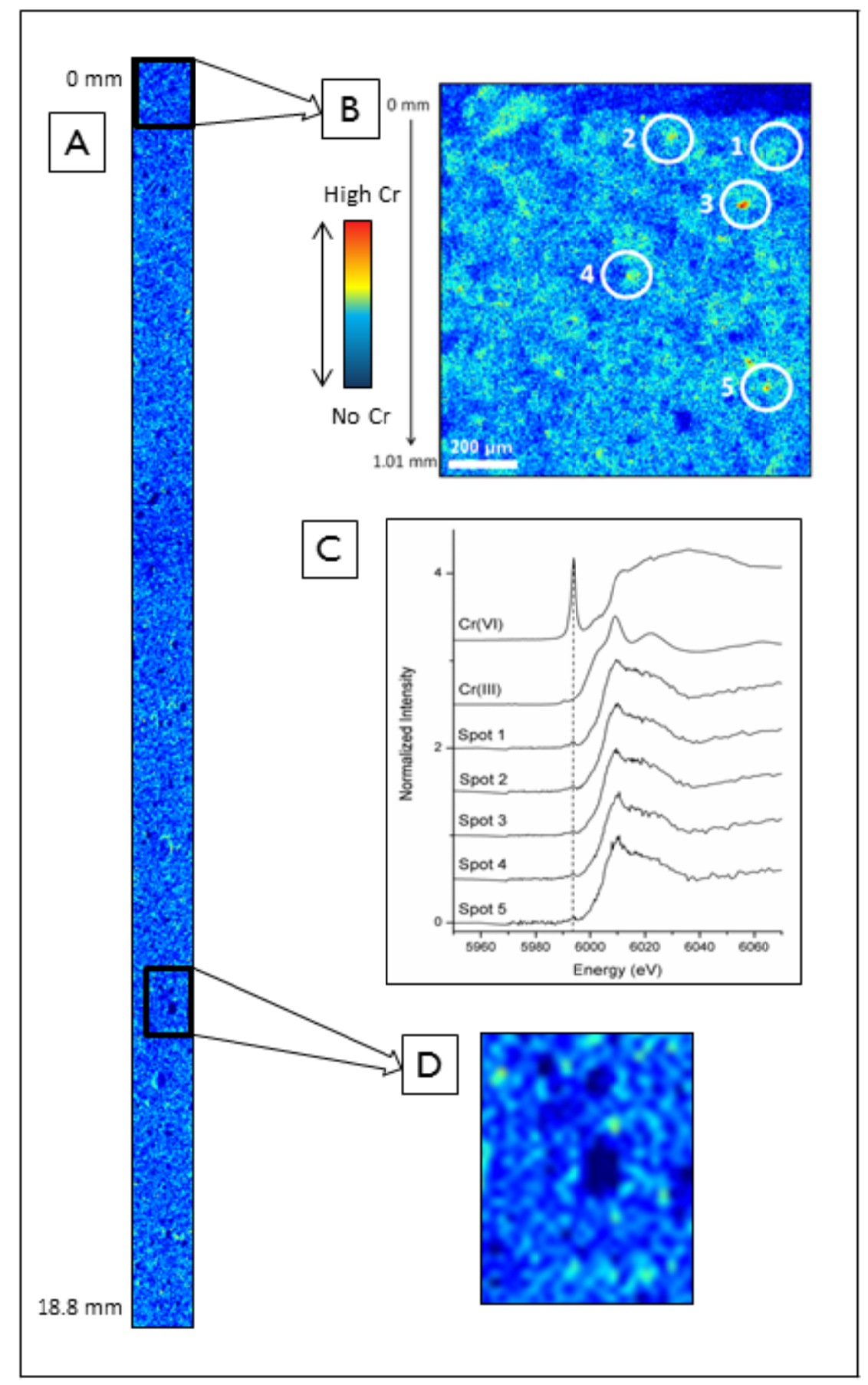

Fig. 2. Results of synchrotron based microprobe analysis of $134 \mathrm{~d}$ aged $\mathrm{Cr} 1000 \mathrm{mg} / \mathrm{kg}$ saltstone sample. A) Total Cr XRF map (0.8mm x $18.8 \mathrm{~mm})$ at the depth of 0 to $18.8 \mathrm{~mm}$. B) $\mathrm{Cr}(\mathrm{VI})$ valence state map $(0.8 \mathrm{~mm} \times 1.01 \mathrm{~mm})$ from 0 to $1.01 \mathrm{~mm}$. For the presentation purpose, the low fluoresce counts were magnified. C) Normalized bulk Cr K-edge XANES spectra of reference compounds and $\mathrm{Cr}(\mathrm{VI})$ hotspots in B. D) A section of total Cr XRF map from Fig. 2A showing a large void (in dark blue) in saltstone matrix. 


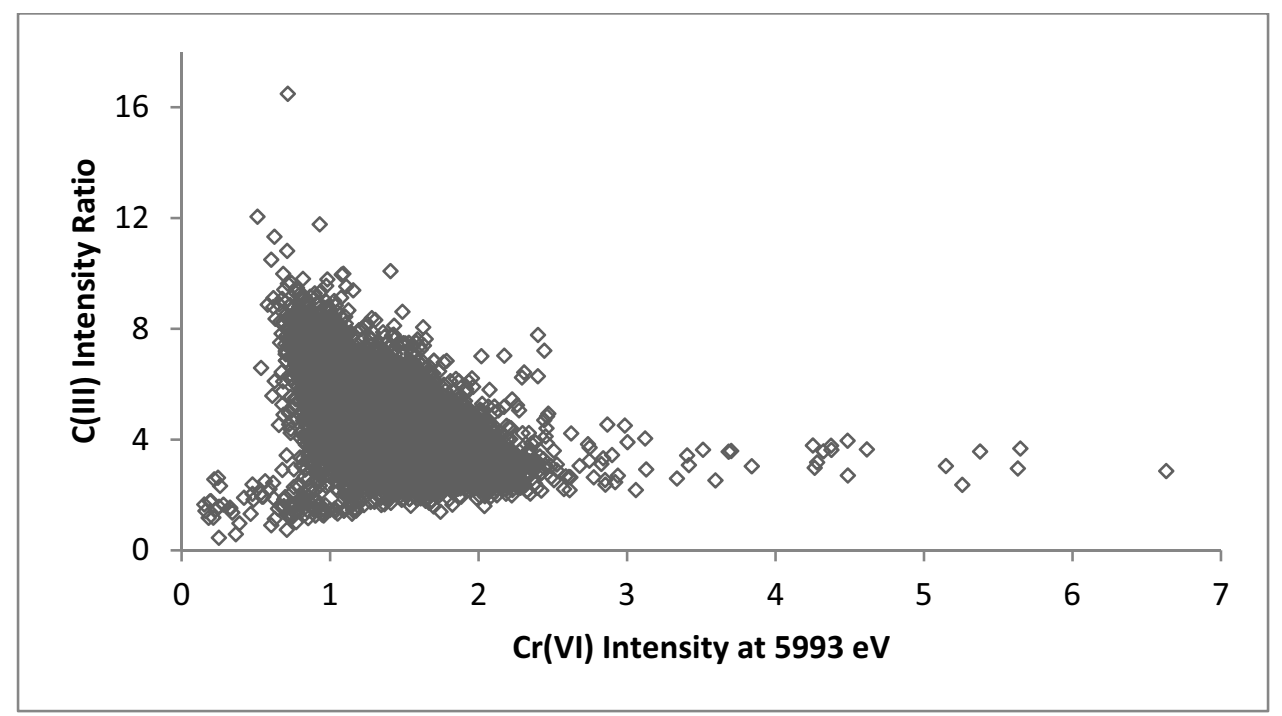

Fig. 3. Correlation plots constructed from synchrotron based microprobe results of $\mathrm{Cr} 1000$ $\mathrm{mg} / \mathrm{kg}$ saltstone (XRF map shown in Fig. 2B). Intensity of the $\mathrm{Cr}(\mathrm{VI})$ pre-edge peak plotted against the ratio of $\mathrm{Cr}(\mathrm{III})(6003 / 5993 \mathrm{eV})$. 